\title{
AIR CONTAMINATION WITH FUNGALS IN MUSEUM
}

\author{
SCARLAT IUliana \\ Faculty of Biology, University of Bucharest, Romania, The National Institute of Research and Development on \\ Occupational Safety “Alexandru Darabont” Bucharest, Laboratory Chemical and Biological Risks Bucharest, \\ Romania, scarlatpamela@yahoo.com
}

HAIDUCU Maria

The National Institute of Research and Development on Occupational Safety “Alexandru Darabont” Bucharest, Laboratory Chemical and Biological Risks Bucharest, Romania, mariahaiducu@yahoo.com

\author{
STEPA Raluca
}

The National Institute of Research and Development on Occupational Safety "Alexandru Darabont” Bucharest, Laboratory Chemical and Biological Risks Bucharest, Romania, steparaluca@yahoo.com

\begin{abstract}
The aim of the studies was to determine the level and kind of fungal contamination of air in museum, deposits patrimony, restoration and conservation laboratories and their effects on health of workers. Microbiological air purity was measured with a SAS-100 Surface Air System impactor. The fungal contamination was observed in all 54 rooms where we made determinations. The highest levels of fungal were recorded at rooms with hygroscopic patrimony objects, eg carpets, chairs, upholstered chairs, books etc. The most species identified included under common allergens: Aspergillus, Penicillium and Mucor. There fungal species belonging to the genus identified in this study, can trigger serious diseases museum workers, such as for example Aspergillus fumigatus, known allergies and toxic effects that may occur. In some places of the museum, occupational exposure limit values to fungi present in the air in the work environment, recommended by the specialized literature, have been overcome.
\end{abstract}

Key words: occupational exposure, allergenic fungi, museum

\section{Introduction}

Interest exposure to bio-aerosols has increased in recent years. This is because exposure to biological agents, both at the workplace and in the residential, is associated with a wide range of adverse health effects, the impact on public health, including infectious contagious diseases, acute toxic effects, allergies and even cancer. The existence of fungi and their proliferation, into the museum complex represent a health risk for workers because, it is known that the majority of their species can cause allergies and are potential producers of mycotoxins [1]. A few years ago, it was found, that infectious diseases are among the most frequently occupational diseases [2]. At museums, restoration and conservation laboratories and at the storages, source of pollution with fungal can be especially artifacts as well indoor dust, bioaerosols, and libraries or other wooden objects. Most of heritage assets deposited at those sites are likely to be colonized by microfungal because, with regard to the chemical structure they are composed mostly of carbohydrates and proteins which is the necessary nutrients to be able to proliferation $[3,4]$. All this biological threats will affect not only the cultural heritage artifacts but also the health of the people working with them. Due to the specific contamination of the old items (textiles and leather are usually recovered from archeological sites and graves), the problems related to the work environment may be considerable different from the usual workplaces that are dealing with biological threats (hospitals and other health care facilities) [5].

The museum work is very important that involve many workers such as archivists, curators, museum technicians, and conservators. According to data provided of U.S. Department of Labor Bulletin 2006, in 2004, was held a Fair Job offers with about 27,000 jobs for occupations archivists, museum technicians, and conservators. Around 34 percent have been recruited for museums, historical sites or similar institutionsand another 16 percent they have chosen to work in educational institutions both in the state and private system, mostly in universities and university libraries. They chose to work in Federal, State, and the local administration, excepting the educational institutions, almost 28 percent. Most Federal 
Government curators are employed at the Smithsonian Institution (the biggest museum and research complex in the world), in the military museums, and other sites and museums that are administered by the United States Department of the Interior. All State governments owning archive or heritage archives departments employin archiving specialists. State and local administrations manages meny libraries and museums in which work curators[6].

This study presents fungal air pollution levels and the effects on health workers in the museum.

\section{Materials and methods}

Air sampling, was performed by applying the Surface Air System, impactor method, where a preset volume of air was aspirated, through to the 219 holes. In this way the airborne fungal spores are obliged to make contact with a counting plate with Sabouraud culture medium complemented with chloramphenicol (which inhibits the growth of bacteria). The method used it was done in accordance with the recommendations by the European standard PN-EN 13098 (2003) / Workplace atmospheres: Guidelines for measurement of airborne micro-organisms and endotoxin [7]. Was used SAS SUPER ISO 100. For eath sampling, the air volume was $200 \mathrm{l}$. All the samples (total 54) was performed in the worker's breathing area. Samples were individualized by labeling and sent to the laboratory, ensuring temperature of $4{ }^{\circ} \mathrm{C}$ during transport. During transport, the samples were protected from the action of sunlight. The samples were incubated for 3 days at $25^{\circ} \mathrm{C}$. The quantitative results of analyzes related fungal air pollution were expressed as the colony forming units per cubic meter of air $\mathrm{CFU} / \mathrm{m}^{3}$. Fungal colony count was performed using automated colony counter SCAN 300. Then its done correctly according to the chart sampler with 219 holes in $90 \mathrm{~mm}$ Petri dishes, because statistical possibility that multiple particles pass through the same hole. Statistical formula used is that of J.Maker.

The morphology of the fungal colonies were analyzed on both the top and reverse as differences can be seen on each surface.

For viewing under a microscope was used the technique Lactophenol Cotton Blue.

\section{Results}

Following the quantitative analysis has resulted out that air contamination with with microfungi has varied between $10^{3}-10^{4} \mathrm{CFU} / \mathrm{m}^{3}$.

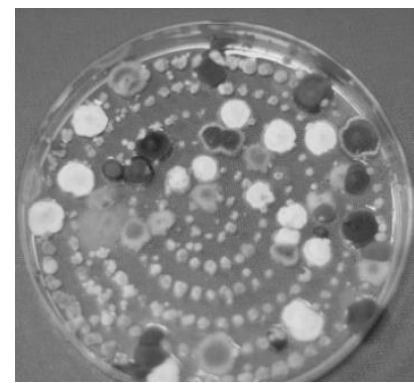

Figure 1: Fungi develop after 3 days

Microscopic examination follows this form and dimensions yeast formations: blastospori, pseudohife, hyphae possibly artrospori. Details such as the presence or absence of capsule burgeoning mode will be retained as important issues for the future identification.

Following the analysis macro- and microscopic, were found: Aspergillus, Penicillium, Mucor but, were identified and colonies of Alternaria, Cladosporium and Fusarium.

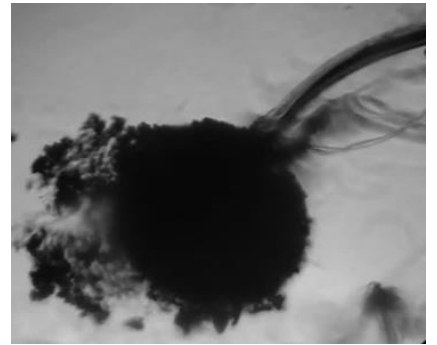

Figure 2: Microscopic image of a spergillus sp. at $\mathbf{x} 400$

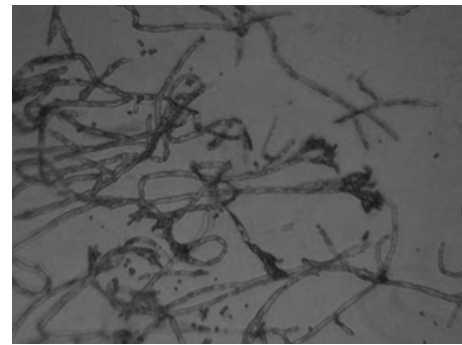

Figure 3: Microscopic image of Penicillium sp. at $\times 400$ 


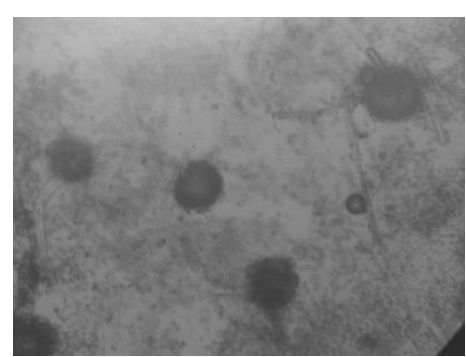

Figure 5: Microscopic image of Mucor at x400

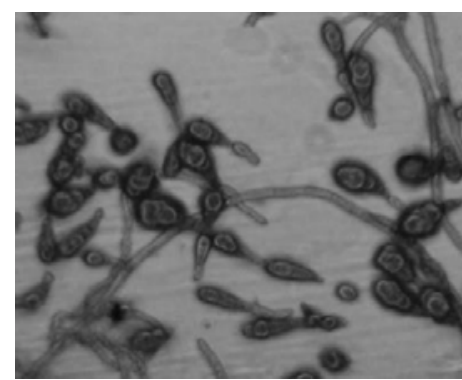

Figure 4: Microscopic image of Alternaria at x400

\section{Discussion}

\section{Aspergillus spp.}

Aspergillus, in general, is not very dangerous but can become, especially for workers who are exposed to this type of fungal daily and workers with chronic lung disease or those with weak immune systems.

A serious health problem caused by theat fungal it is the aspergillosis, which is an infaction or allergic reaction [8]. A. fumigatus is classified by the GD 1092/2006 in the second group risk.

\section{Penicillium}

Penicillium species are fungi that prefer cooler climates and moderate, usually present where available organic material. Penicillium can occur even if the relative humidity is low, as long as there is sufficient moisture available in a given area.

Penicillium, as well as Aspergillus is not very dangerous can trigger the disease all age groups. The symptomatology of allergy range from mild to the serious wheezing, coughing, post nasal drip, asthma, and other respiratory symptoms [9. Penicillium marneffei is the most dangerous of Penicillium spp. and it is found in the second group risk HG 1092/2006. A major cause of opportunistic infection, is Penicillium marneffei, especially in patients with AIDS, said in a study made by Desakorn 10].

\section{Mucor}

Mucor is a dangerous kind of mold that can adversely affect the respiratory system of workers, most often settling sinuses. Like any allergies, and that produced by micromycetes, may be manifested by rhinitis, conjunctivitis, asthmatic crises, etc. People who are very sensitive, reacts to the spores in air cargo, showing allergic reactions in the absence of a localized the outbreak, especially in wet weather (allergic phenomenons disappear only in winter, when the amount of spores in the air is reduced by $75 \%$, or summer when the weather is warm and dry air). Mycosis produced by Mucor mucedo called mucoroză. In susceptible individuals, inhalation or ingestion of white mold spores causes allergic reactions [11].

Regardless of the forms that are found in air conditioning pathogens and pathogenic organisms can cause sickness exposed primarily through inhalation of contaminated suspension, causing respiratory diseases, laryngitis, dermatitis, allergic bronchitis; infections of the skin, nails, eyes, also can affect the mucous membranes, skin, hair growth, internal organs, lungs, bronchi, sinuses, etc.[9].

People who come into contact with contaminated objects are directly exposed to occupational diseases caused by pathogens.

The amount varies depending on the biological components of the season, the activities carried out, the location of the building, this infested items.

Table 1: Recommended limits for exposure of the fungal colonies

\begin{tabular}{|c|c|c|}
\hline Category & Houses $\left(\mathrm{cfu} / \mathrm{m}^{3}\right)$ & Non-industrial indoor environments $\left(\mathrm{cfu} / \mathrm{m}^{3}\right)$ \\
\hline very low & $<50$ & $<25$ \\
\hline low & $<200$ & $<100$ \\
\hline intermediate & $<1000$ & $<500$ \\
\hline high & $<10000$ & $<2000$ \\
\hline very high & $>10000$ & $>2000$ \\
\hline
\end{tabular}

Source: European Collaborative Action / Indoor Air Quality \& Its Impact On Man

Quantitative analysis revealed air microbiological contamination with fungi at the level ranging from $10^{3}-$ $10^{4} \mathrm{CFU} / \mathrm{m}^{3}$, which means that the limit is exceeded recommended of $5 \times 10^{2} \mathrm{CFU} / \mathrm{m}^{3}$. Indications of literature can be considered as indicative values in the monitoring of exposure to biological agents and to highlight effective prevention and protection measures taken by the employer.

Museum work environment favors the emergence and growth of microorganisms what they need for survival and multiplication of an organic food source and a high humidity environment [12]. Heritage objects textile and leather are environments for the development of molds and bacteria. 


\section{Conclusions}

National law provides occupational exposure no limit values for biological agents. Risk assessment of exposure to biological agents is in accordance with Government Decision no. 1092 2006, by identifying the types of biological agents present in the workplace and their classification into 4 groups of biological risk.

At the work posts examined, although no clearly visible signs of mould contamination could be found, the study revealed abundant microscopical fungi, with the predominant species of Aspergillus, Penicillium and Mucor.

Mold found in museum environments are part of the second biological agents of risk group, defined by the Government in 1092/2006 as biological agents that can cause human disease and constitute a hazard to workers; their propagation in the community is unlikely; There is generally an effective treatment or prophylaxis [13].

from this study we can say, that hygienic conditions at that time at the workplaces examined have not been very satisfactory as recommended of literature. There is the risk of fungal contamination and theat it can be a potential risk for employers health. It is necessary to remedial the activities on the part of the employers.

\section{Acknowledgement}

This work was funded by the ANCS, PN-II-PT-PCCA-2011-3-1742 project, "Improvement of occupational environment quality in cultural heritage deposits. Validation of gamma radiations treatment of textile and leather cultural goods (TEXLECONS)” contr. no. 213/2012.

\section{References}

- Azizollah E.; Saeid K.; Sharareh L.; Fariba M. Allergenic fungi in deteriorating historic objects of Shashrekord Museums, in Iran , Jundishapur Journal of Microbiology, 4(4): 261-265, 201;

- Lipiniska-Ojrzanowska A, Wittczak T, Krzyczmanik D, Palczynski C, Walusiak- Skorupa J. Invasion by trichinae in the patient hospitalized with suspicion of occupational borreliosis: a case report. Med Pr 62:73e6., 2011;

- Kowalik R.: Microbiodeterioration of library materials. Microbiodecomposition of library materials, Par 2: Microbiodecomposition of auxiliary materials, Chapter 5-9, Restaurator , Vol 6, pp. 61-115,( 1984);

- Katarzyna, Z. J., Anna, K.., Małgorzata, P., Irena, S., S., Microbiological contamination with moulds in work environment in libraries and archive storage facilities, Ann Agric Environ Med, Vol 15, pp. 71-78, (2008);

- Nisipeanu, S., Haiducu, M., Scarlat, I., Chiurtu, R., Avram R. Modern methods of reducing biological risk factors from cultural heritage deposits, 6th Interational Conference of Manufacturing Science and Education-MSE, 2013;

- U.S. Bureau of Labor Statistics, U.S Department of labor, Ocupational Handbook 2006-07 Library Edition, Bulletin 2600. Superintandent of Documents, US Government Printing Office, Washington, DC (2006);

- European standard PN-EN 13098, Workplace atmosphere - Guidelines for measurement of airborne micro-organisms and endotoxin, (2003);

- Lazăr V., Medical Microbiology, Ed. Universitatii, Bucharest, Romania (2001);

- Lazăr, V., Chifiriuc, C., Cernat R., Immunology, Ed. Universitatii, Bucharest, Romania (2006);

- Desakorn, V., Smith, M. D., Walsh, A. L., Simpson, A. J. H., Sahassananda, D., Rajanuwong, A., Wuthiekanun, V., Howe, P., Angus, B. J., Suntharasamai, P., White, N. J. Diagnosis of Penicillium marneffei Infection by Quantitation of Urinary Antigen by Using an Enzyme Immunoassay Journal of Clinical Microbiology, Vol 37, Nr. 1, pp. 117-121, (1999);

- Stoica, I., Vassu-Dimov, T., Săsărman, E., Molecular biology and taxonomy of microorganisms: Microbial Culture collection, Ed. Arvin Press, Bucharest, Romania(2002);

- $\quad$ Moise, I., Virgolici, M., Stanciu, C., Nisipeanu, S., Balan, Z., The treatment with ionizing radiation: A chance for the future of archives, Restitutio - Newsletter of Conservation Restoration, vol. 3, pp.130-142. (2010);

- Government Decision no. 1092 of 16.08 .2006 on the protection of workers from risks related to exposure to biological agents at work. 